\title{
Деякі аспекти діагностики та лікування синдрому діабетичної стопи
}

\begin{abstract}
Мета роботи: оцінити діагностичну та лікувальну цінність предикторів синдрому діабетичної стопи у хворих на цукровий діабет 2-го типу.

Матеріали і методи. Проведено аналіз діагностики та лікування 142 пацієнтів з ускладненнями цукрового діабету, лікованих у хірургічних відділеннях клініки хірургї та ендоскопії ФПДО Львівського національного медичного університету імені Данила Галицького у 2017-2018 рр. Виконано 156 операційних втручань з приводу хірургічного ускладнення діабету - синдрому діабетичної стопи. Середній вік пацієнтів - (56,2 $\pm 11,5)$ року $(61,2 \%$ чоловіки). У всіх хворих верифіковано тяжкий ступінь цукрового діабету. Тривалість захворювання склала $(12,1 \pm 4,4)$ року. Всі пацієнти мали глибокі ураження стопи (III-IV стадії за Вагнером). Ішемічна форма діабетичної стопи становила 25,1 \%, змішана - у 33,4 \% та нейропатична - у 41,5 \%.

Результати досліджень та їх обговорення. 3 метою покращення тактики та результатів операційного лікування гнійнонекротичних уражень стопи ми враховували показники кісточково-плечового індексу та ендотелійзалежної вазодилатації плечової артерії як основні діагностично-прогностичні маркери стенотично-оклюзійних уражень судин нижніх кінцівок.
\end{abstract}

Ключові слова: цукровий діабет; діабетична стопа; оперативне лікування.

Постановка проблеми і аналіз останніх досліджень та публікацій. Синдром діабетичної стопи (СДС) є найбільш небезпечним хірургічним ускладненям цукрового діабету 2-го типу (ЦД-2). За даними світового реєстру СДС є причиною госпіталізації кожного четвертого пацієнта 3 діабетом, у кожного сьомого проводять високу ампутацію кінцівки [3, 5]. П’ятирічне виживання після ампутації кінцівки складає 39-68 \% [2].

Ендотелійна дисфункція $є$ основним чинником патогенезу атеросклерозу. Згідно 3 даними досліджень ендотелійзалежна вазодилатація (ЕЗВД) порушується у хворих на ЦД-2 з обструктивним ураженням артерій. За своїми морфологічними особливостями діабетичні мікро- та макроангіопатії схожі до атеросклеротичного ураження відповідних судинних басейнів. Проте зміни судин у хворих на діабет виникають на 10-15 років швидше, ніж у загальній популяції [3].

Важливо зазначити, що при стійкій гіперглікемії порушується структура стінки капіляра, що призводить до потовщення базальної мембрани та порушує еластичність судинної стінки, що, у свою чергу, порушує функцію її дилатації. В нормі ендотелій синтезує оксид азоту, ендотелін, простогландини, які є важливими чинниками в регуляції вазоконстрикції, що забезпечують дотримання судинного тонусу, регулюють кровотік [2, $3,4]$. Основна дія вазодилятатора направлена на гладком'язові клітини стінки судини, яка прилягає до ендотелію [1, 3, 4].

Хірургічне лікування гнійно-некротичних уражень стопи $є$ актуальною проблемою, вирі- шення якої потребує мультидисциплінарного підходу та співпраці різних спеціалістів. Необхідно враховувати економічні аспекти, які призводять до істотних економічних витрат як через прямі медичні витрати, так і через стійку втрату працездатності.

Мета роботи: оцінити діагностичну та лікувальну цінність певних предикторів синдрому діабетичної стопи у хворих на цукровий діабет 2-го типу.

Матеріали і методи. Проспективно обстежено 142 хворих з гнійно-некротичними ураженнями стопи пролікованих у хірургічних відділеннях клініки хірургії та ендоскопії ФПДО Львівського національного медичного університету імені Данила Галицького - КНП “Перша міська лікарня ім. Князя Лева” та КНП “Клінічна лікарня швидкої медичної допомоги м. Львів” у 2017-2019 рр. Середній вік пацієнтів - $(56,2 \pm 11,5)$ року, частка працездатного віку склала 48,3 \%. Переважали чоловіки - 61,2 \%. Тривалість ЦД склала $(12,1 \pm 4,4)$ року, синдрому діабетичної стопи $(3,7 \pm 1,8)$ року.

3 метою оцінки характеру ураження стопи застосовували класифікацію клінічних ушкоджень WIFI, яка враховувала стан рани (W-Wound), ступінь ішемії (I-Ischemia) та поширення інфекційного процесу на стопі (FI-Foot Infection) [6]. Відповідно до форми та глибини ураження нагнійних процесів стопи користувалися класифікацією Wagner-Maggitt (1978р.), у модифікації Bolton (1996 p.) [7]. 


\section{З ДОСВІДУ РОБОТИ}

Тривалість гнійно-некротичних ускладнень (ГНУ) до моменту госпіталізації склала $(12,5 \pm 1,9)$ дня. У всіх хворих була тяжка форма ЦД. Тяжкість ЦД-2 контролювали загальноклінічними аналізами, ступенем глікемії та добової глюкозурії, кліренсом кетонових тіл у сечі, рівнем компенсації діабету за рівнем глікозильованого гемоглобіну та ступенем ГНУ стопи.

Нейропатичну форму СДС діагностовано у 41,5 \%, ішемічну - у 25,1 \%, змішану - у 33,4 \% хворих. Враховуючи принцип етапності проведено 156 операційних втручання, з яких у 22 пацієнтів виконано два втручання, у 8 - три, у 6 - чотири та більше. Середня тривалість операції склала $(29,4 \pm 8,2)$ хв.

Проведені наступні операційні втручання: черезплеснову ампутацію пальців стопи виконано у 63 (40,4 \%) хворих, розкриття флегмони стопи 3 некректомією - у 34 (21,8 \%), черезплеснева ампутація двох пальців із розкриттям флегмони стопи - у 20 (12,8 \%), черезплеснова ампутація стопи за Шарпом - у 16 (10,2 \%), ампутацію стопи за Шопаром - у 11 (7,1%), ампутацію стопи за Лісфранком - у 5 (3,2 \%), ампутацію нижньої кінцівки на рівні стегна у 4 (2,6 \%), ампутацію нижньої кінцівки на рівні гомілки - 3 (1,9 \%).

Тривалість перебування в стаціонарі склала $(23,2 \pm 7,4)$ доби та залежала від тяжкості ГНУ стопи, ступеня метаболічних та електролітних порушень, а також тривалості ЦД та СДС.

Усім пацієнтам виконано бактеріологічне дослідження гнійних виділень з ран і верифікацією флори $з$ метою призначення раціональної антибіотикотерапії.

В алгоритм дослідження хворих на СДС включали ультразвукове ангіосканування артерій нижніх кінцівок $з$ визначенням стану інтіми-медії судини, ендотелійзалежної вазодилатації та кісточково-плечового індексу. Ступінь ендотелійзалежної вазодилатації визначали шляхом збільшення діаметра плечової артерії за допомогою проби з реактивною гіперемією за методикою D. Cellenater (1992). Поліпозиційне рентгенологічне дослідження стопи дозволяло виявити ураження кісткової тканини та остеомієліт. Пацієнтів комплексно консультовано суміжними спеціалістами (ендокринологом, кардіологом, неврологом та окулістом).

Результати дослідження та їх обговорення. Враховуючи етапи дослідження, світові рекомендації та власний досвід об’єм та радикальність операційного втручання визначали після деталь- ної клінічної діагностики пацієнта, рівня глікемії та лабораторних даних (коагуляційного потенціалу крові та біохімічних показників), інструментальних методів обстеження (ультразвукового обстеження судин та рентгенологічного дослідження стопи). Особливого значення надавали знеболенню ненаркотичним середниками, оскільки переконані, що активність пацієнта $є$ ефективною профілактикою гнійно-септичних та тромбоемболічних ускладнень.

На нашу думку, основним фактором ефективного лікування є визначення форми СДС. Сучасним “золотим стандартом” вважаємо ультразвукове обстеження артерій нижніх кінцівок у режимі тріплексної візуалізації кровотоку з можливістю застосування ефекту Допплера.

Так, при вказаному дослідженні ми діагностували різні ступені макроангіопатії у 98 пацієнтів (62,8 \%). У хворих з гнійно-некротичними ураженнями стоп показник відносного розширення плечової артерії склав $(9,89 \pm 0,81)$ \% і на 38,9 \% був нижчим порівняно з показником здорових осіб $(15 \pm 1,22) \%,(p<0,01)$, що свідчить про прогресування атеросклеротичних процесів у хворих на діабет.

Показники кісточково-плечовий індексу (КПI) та ЕЗВД плечової артерії вважали провідними діагностично-прогностичними маркерами стенотично-оклюзійних уражень судин нижніх кінцівок. Враховуючи світові рекомендації, реалії сьогодення та впровадження страхової медицини вважаємо вирішення питання про ампутацію кінцівки не можливе без визначення КПI та ЕЗВД. Так, у пацієнтів, у яких виконано ампутації на рівні

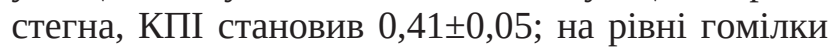

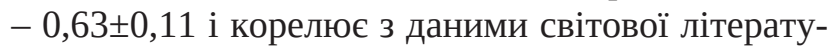
ри та рекомендацій Трансатлантичного міждисциплінарного консенсусу 3 лікування захворювань артерій нижніх кінцівок (Trans-Atlantic InterSociety Consensus, TASC).

Висновки. 1. Ефективність діагностично-лікувальної програми у хворих на діабет 2 типу залежить від мультимодального підходу та чіткого діагностично-лікувального алгоритму із застосуванням новітніх методів лікування та діагностики СДС.

При комплексному лікуванні ГНУ стопи у хворих на ЦД 2 типу необхідне визначення КПI та ЕЗВД плечової артерії як основних діагностичних маркерів атеросклеротичних уражень артерійних басейнів.

Визначення КПІ та ЕЗВД, на ранніх стадіях СДС, є цінними прогностичними маркерами. 


\section{З ДОСВІДУ РОБОТИ}

\section{СПИСОК ЛІТЕРАТУРИ}

1. Дисфункция эндотелия у больных гипертонической болезнью / А. И. Мартынов, Н. Г. Аветян, Е. В. Акатова [и др.] // Кардиол. - 2005. - № 10. - С. 101-104.

2. Ефимов А. Синдром диабетической стопы / А. Ефимов,

С. Болгарская // Ліки. - 2005. - № 5 (94). - С. 45-53.

3. Заремба В. С. Синдром діабетичної стопи : навч. посіб. /

В. С. Заремба. - Львів, 2012. - 158 с.

4. Малая Л. Т. Эндотелиальная дисфункция при патологии сердечно-сосудистой системы / Л. Т. Малая, А. Н. Корж, Л. Б. Балковая. - Х. : Торсинг, 2000. - 432 с.

5. Тронько М. Д. Сучасний стан та перспективи розвитку фундаментальної та клінічної ендокринології в Україні. Доповідь на VП з'їзді асоціації ендокринологів України (Київ, 15-18 травня) / М. Д. Тронько // Здоров’я України. - 2007. № 13-14 (170-171). - С. 48-51.

6. Executive summary: 2012 Infectious Diseases Society of America clinical practice guideline for the diagnosis and treatment of diabetic foot infections / B. A. Lipsky, A. R. Berendt, P. B. Cornia [et al.] // Clin. Infect. Dis. - 2012. - Vol. 54 (12). - P. 1679-1684.

7. Frykberg R. G. Surgical off-loading of the diabetic foot / R. G. Frykberg, Bevilacqua, G. Habershaw // J. Vasc. Surg. 2010. - Vol. 52 (Suppl. 3). - P. 44S-58S.

\section{REFERENCES}

1. Martynov, A.I., Avetyan, N., \& Akatova, Ye.V. (2005). Disfunktsiya endoteliya $\mathrm{v}$ bolnykh gipertonicheskoy boleznyu [Endothelial dysfunction in patients with hypertension]. Kardiologiya - Cardiology, 10, 101-104 [in Russian].

2. Yefimov, A., \& Bolgarskaya, S. (2005). Sindrom diabeticheskoy stopy [Diabetic foot syndrome]. Lekarstva - Medicines, 5 (94), 45-53 [in Russian].

3. Zaremba, V.S. (2012). Syndrom diabetychnoi stopy: Navchalnyi posibnyk [Diabetic foot syndrome: manual]. Lviv [in Ukrainian].

4. Malaya, L.T., Korzh, A.N., \& Balkovaya, L.B. (2000). Endotelialnaya disfunktsiya pri patologii serdechno-sosudistoy sistemy [Endothelial dysfunction in the pathology of the cardiovascular system]. Moscow: Torsing [in Russian].
5. Tronko, M.D. (2007). Suchasnyi stan i perspektyvy rozvytku fundamentalnoi i klinichnoi endokrynolohii v Ukraini. Dopovid na VII zizdi assotsiatsii endokrynolohiv Ukrainy (Kyiv, 1518 Travnia) [The current state and prospects of development of fundamental and clinical endocrinology in Ukraine. Report at the VII Congress of the Association of Endocrinologists of Ukraine (Kyiv, May 15-18)]. Zdorovia Ukrainy - Health of Ukraine, 1314 (170-171), 48-51 [in Ukrainian].

6. Lipsky, B.A., Berendt, A.R., \& Cornia, P.B. (2012). Executive summary: 2012 Infectious Diseases Society of America clinical practice guideline for the diagnosis and treatment of diabetic foot infections. Clin. Infect. Dis., 54 (12), 1679-1684.

7. Frykberg, R.G., Bevilacqua, Habershaw, G. (2010). Surgical off-loading of the diabetic foot. J. Vasc. Surg., 52 (Suppl. 3), 44S-58S.

Отримано 31.10.2019

Електронна адреса для листування: fednaz@ukr.net

V. S. ZAREMBA, N. R. FEDCHYSHYN, R. L. BOKHONKO, H. I. HERYCH

Danylo Halytskyi Lviv National Medical University

\section{SOME ASPECTS TO DIAGNOSIS AND TREATMENT OF DIABETIC FOOT SYNDROME}

The aim of the work: evaluation of the diagnostic and therapeutic value of predictors of diabetic foot syndrome in patients with type 2 diabetes.

Materials and Methods. There was an analysis of diagnostic features and complex surgical treatment of 142 patients, operated in Lviv Centre of Diabetic foot in 2017-2018, who had 156 operative intervention rather insular diabetes complicated by purulently-necrotic stinging of foot. The average patients age $(56.2 \pm 11.5)$ years, $61.2 \%$ of them - men. The mild form of disease was in $33.1 \%$, moderate severity - in $45.3 \%$, severe - in $21.6 \%$. The duration of disease was (12.1 \pm 4.4 ) years. All patients had deep lesions of foot (III-IV according to Wagner). Ischemic form of diabetic foot was in $25.1 \%$, mixed form - in $33.4 \%$ and neuropatic - in $41.5 \%$.

Results and Discussion. In order to improve the tactics and results of surgical treatment of necrotic injuries of the foot, we considered the value of the ankle-brachial index and endothelin-dependent vasodilation of the brachial artery, as the main diagnostic and prognostic markers of the occlusive arterial lesion in the feet.

Key words: diabetic foot syndrome; operating treatment; diabetes. 
В. С. ЗАРЕМБА, Н. Р. ФЕДЧИШИН, Р. Л. БОХОНКО, Г. И. ГЕРИЧ

Львовский национальный медицинский университет имени Данила Галицкого

\section{НЕКОТОРЫЕ АСПЕКТЫ ДИАГНОСТИКИ И ЛЕЧЕНИЯ СИНДРОМА ДИАБЕТИЧЕСКОЙ СТОПЫ}

Цель работы: оценить диагностическую ценность предикторов синдрома диабетической стопы у пациентов с сахарным диабетом 2-го типа.

Материалы и методы. Проведен анализ диагностических признаков и комплексного хирургического лечения 142 пациентов, которые лечились во Львовском центре диабетической стопы в 2017-2018 годах. Выполнено 156 оперативных вмешательств по поводу диабета, осложненного гнойно-некротическим заболеванием стопы. Средний возраст пациента (56,2 $\pm 11,5)$ года; 61,2 \% из них - мужчины. Легкая форма заболевания составила 33,1 \%, средней степени тяжести - у 45,3 \%, тяжелая - у 21,6 \%. Длительность заболевания составила $(12,1 \pm 4,4)$ года. Все пациенты имели глубокие поражения стопи (III-IV класс по Вагнеру). Ишемическая форма диабетической стопи составляла 25,1 \%, смешанная форма - 33,4 \% и нейропатическая - 41,5 \%.

Результаты исследований и их обсуждение. С целью улучшения тактики и результатов операционного лечения гнойно-некротических поражений стопы мы учитывали показатели лодыжечно-плечевого индекса и эндотелийзависимой вазодилатации плечевой артерии как основные лечебно-прогностические маркеры стенотично-окклюзионных поражений сосудов нижних конечностей.

Ключевые слова: диабетическая стопа; оперативное лечение; сахарный диабет 